October 3, 2002

\title{
GOAL/COMPLETION ABSTRACT
}

\section{The Wilbur Wright College Environmental Technician Training Program}

Funding Received: $2,407,408.91$

Project Period: September 15, 1993 to June 15, 1996

In September of 1993 the Department of Energy through Argonne National Laboratory awarded Wilbur Wright College a grant to develop an Environmental Technician training program. Since that time many of the anticipated goals have been accomplished. Today as a result of this grant the Environmental Technology Program at Wilbur Wright an active and viable training program.

At the commencement of the DOE grant, the primary goals included developing a comprehensive curriculum for the best possible training of environmental technicians as well as the building of a state of the art facility to serve these students. The specific goal of the creation of the Environmental Technology Department was to train participants in identifying, auditing, sampling, and managing hazardous substances, handling in routine use, as well as responding to chemical emergencies, and in minimizing the generation of hazardous waste through pollution prevention.

The development of the facilities included a state of the art classroom with projection equipment and satellite connection, a computer lab, and a fully equipped wet science laboratory, and a hands-on training laboratory with training equipment including a variety of respirators, protective clothing, sampling equipment, test drums, and other items used for the protection of people and the environment.

The program was intended to make available a range of education options for students. Students could choose to work towards a Certificate in Environmental Technology, or a course of study towards an Associates degree in Applied Science, which could then be transferred to a four year institution. The program also strove to serve as a leader in 40 -

DOE Patent Clearance Granted

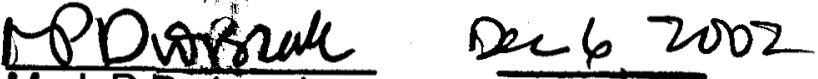

Mark P. Dudrscak Dáte 


\section{DISCLAIMER}

This report was prepared as an account of work sponsored by an agency of the United States Government. Neither the United States Government nor any agency thereof, nor any of their employees, makes any wartanty, express or implied, or assumes any legal liability or responsibility for the accuracy, completeness, or usefulness of any information, apparatus, product, or process disclosed, or represents that its use would not infringe privately owned rights. Reference herein to any specific commercial product, process, or service by trade name, trademark, manufacturer, or otherwise does not necessarily constitute or imply its endorsement, recommendation, or favoring by the United States Government or any agency thereof. The views and opinions of authors expressed herein do not necessarily state or refiect those of the United States Government or any agency thereof. 


\section{DISCLAIMER}

Portions of this document may be illegible in electronic image products. Images are produced from the best available original document. 
hour HAZWOPER training, as well as $\mathbf{8}$ hour OSHA refresher training for a variety of business and government entities in the Chicago area and surrounding states.

Outreach to the Chicagoland area industry, government organizations, and younger students about to choose a career path was seen as the method for recruiting students. This effort has been successful.

Many successful student outcomes can be documented. The Environmental Technology Department recently completed a two-year technical course at Argonne National Labs. Sixteen Argonne employees of the Operations Division received their Certificates in Environmental Technology. Twelve students also received Certificates in the last two years through the program at Wright College. A wide range of students have been successfully trained in this program, including people working in such diverse fields as medicine, engineering, administration, and workers for the City of Chicago Department of Environment. We currently have 25 students working towards the completion of certificates and degrees in Environmental Technology. The City Colleges of Chicago, District 508, as well as Charles Guengerich, Ph.D., President of Wilbur Wright College, have continued to support the program after the completion of the grant. The Environmental Technology Department has come to be considered a valuable part of the City College of Chicago system. It is also the only program of its kind in the State of Illinois.

The Department has also been working in conjunction with HMTRI in offering 40hour HAZWOPER classes, a helpful resource for local business and government agencies. There is currently work being done to implement an online training sequence leading to an 18 credit certificate, as well as bringing other courses within the Department to a wider audience.

Because of these accomplishments the Environmental Technology Department, originally funded by the DOE, must be considered a success that continues after the completion of the grant. 